\title{
Shakespeare's Last Humanist
}

\author{
ALAN FISHER
}

The personage I refer to in my title is Polonius, the long-winded chief counsellor at the Danish court in Elsinore. It is somewhat odd that criticism does not place him in the humanist role more often, since, as I hope to show, he fits it disconcertingly well. But if the fit is disconcerting, that would explain its not being commonly asserted. In the long debate over just what to make of Polonius, no one has proposed that he is a truly respectable character, and critics are not to be blamed if they do not wish to see him as a precursor of themselves. This paper does not propose that he is respectable, either, and if I make him something like a humanist shoe, modern-day humanists are not obliged to wear it. But to the bundle of things that Polonius does for this play - as foil for Hamlet, as comic relief, as atmospheric figure to help set the tone of Hamlet's world, as a sadly ordinary person caught up in events too large for his mediocrity I want to add one thing more. He is also representative of a whole manner of thinking of which the play is aware and which it examines critically. Polonius is a courtier, a father, a counsellor, an intriguer, a literary critic, and a fool; he is also a humanist - or to be more precise, he is a recognizable version of the kind of man that a humanist training was supposed to produce.

The moment at which this connection is most evident is Act I, scene iii, when he sends Laertes off to France with some "precepts" that Laertes is to "character" in his memory:

Give thy thoughts no tongue,

Nor any unproportion'd thought his act.

Be thou familiar, but by no means vulgar.

Those friends thou hast, and their adoption tried,

Grapple them unto thy soul with hoops of steel,

But do not dull thy palm with entertainment

Of each new-hatch'd, unfledg'd courage. Beware

Of entrance to a quarrel, but being in,

Bear't that th' opposed may beware of thee. 
Give every man thy ear, but few thy voice,

Take each man's censure, but reserve thy judgment.

Costly thy habit as thy purse can buy,

But not express'd in fancy, rich not gaudy,

For the apparel oft proclaims the man,

And they in France of the best rank and station

Are of a most select and generous chief in that.

Neither a borrower nor a lender be,

For loan oft loses both itself and friend,

And borrowing dulleth th' edge of husbandry.

This above all: to thine own self be true,

And it must follow, as the night the day,

Thou canst not then be false to any man. $(1.3 .59-80)^{1}$

The modern tendency is to find these precepts unimpressive. Harry Levin laughs at them as "etiquette rather than ethics" - and productions of the play will often help us laugh by making Laertes fidget while his father recites them. One production, earlier this century, had Polonius pull a little book out of his pocket and read the precepts from it, ${ }^{3}$ demonstrating by stage business that they are not to be "charactered" in memory, since even the man who preaches them does not have them charactered in his. But this matter of "charactering" in the memory is a good bit more serious than that. The metaphor is from the standard schoolboy enterprise of keeping commonplace books. The pupil made up a quire of blank pages and apportioned them among a number of predetermined general headings. Whenever he encountered a passage in his daily reading that could be lifted from its context and placed under one of these general headings, he wrote it down in this little book. Eventually, the book would fill with these passages, or "places," and he would have produced his own manual of useful and elegant quotations. His primary use for these was to spice up his own writing, but theory held that he was also storing his memory with them. And since they were common precepts, good on a wide variety of occasions, the pupil would naturally combine them with experience from his own life; they would give that experience shape, and the combination of precept and experience would make him wise, fit to give counsel and regulate affairs. Laertes's mind, therefore, is a commonplace book, and Polonius is offering a few choice precepts to write down in it. Represented in this moment is one of the fundamental transactions of humanist education: the transfer of sage generality from an authoritative source to oneself, and the storing of the memory therewith. 
Two scenes later, this same idea shows up in a radically different context, and prepared for it as we are by Polonius and Laertes, we are able to catch its resonance. Hamlet's suspicions of foul play and infidelity have been confirmed by the ghost, whose parting words to Hamlet are "Remember me." "Remember thee!" cries Hamlet to no one in particular,
Yea, from the table of my memory
I'll wipe away all trivial fond records,
All saws of books, all forms, all pressures past
That youth and observation copied there,
And thy commandement all alone shall live
Within the book and volume of my brain,
Unmix'd with baser matter. (1.5.97-104)

All the commonplaces of his former instruction, reading, and experience are now to be cancelled, sponged out, placed under erasure; in their place, one precept only: "one may smile, and smile, and be a villain" (1.5.108). This shall be the master commonplace - indeed, the only commonplace for any context Hamlet now occupies, for he is sure, "at least" that his precept "may be so in Denmark," and Denmark, as he later says, is now his "prison." The stage direction which most modern editions interpolate here, which has Hamlet actually write this precept down, is unnecessary and even misleading. His memory is "book" enough, and having exchanged his old memory for this new one, he is literally re-educated - and no longer in the humanist mode.

The maxims of Polonius, on the other hand, are typically humanist. This cannot reflect much credit on humanism for those who are unimpressed with the maxims or with thinking in maxims. The "language of Polonius," as one critic has recently declared, is the language of "aphorism - the popular sententiae of generalizations divorced from particular significance, the verbal platitudes of phrase thinking." 4 shall return to the matter of "phrase thinking" presently, because humanism did a lot of it and it is central to my argument. It is enough to note now, however, that the modern prejudice against such thinking tends to keep us from looking at how it works. As for the actual content of the phrases, that, too, has met a mixed reception. The majority view is disapproval. Edward Dowden, in the last century, declared sadly that they were "not the outflow of a rich or deep nature"; Derek Traversi finds in them a "spirit of courtly dissembling which the speaker, in his position of trusted, experienced authority, so weightily upholds"; and Lynda Boose, quite recently, sums them up as a kind of sinister mediocrity: "distrust everyone, be shrewd, be prudential, always 
stack the odds in your favour, and always cloak your real intentions." 5 Levin Schcking, on the other hand, describes them as "flashes of reason" that actually "break the unity" of a character whose primary job in the play is to be a self-assured fool. One could save the unity by treating the precepts with irony, Schcking concedes, but that is a "most questionable exegetical trick," especially in view of what he calls "the beauty of the thoughts." He prefers to regard them as quasi-authorial gnomic outbursts, Shakespeare himself speaking through his character in this one place, thus satisfying "the demand of the time that a tragedy should be sententious." 6 This may seem an exegetical trick even more questionable than invoking irony, but Josephine Waters Bennett has shown that these precepts would certainly have been recognized as gnomic wisdom. They seem to have been taken from a letter of Isocrates, a Latin translation of which was used as a standard text and source of commonplace gathering by the first and second forms of Elizabethan schools. They would not only have been recognized, she argues, but would have been recognized as kids' stuff. Elizabethans, she thinks, would have laughed at the grave old counsellor reciting saws for seven-year-olds. ${ }^{7} \mathrm{G}$. K. Hunter points out, however, that maxims just like these were appearing in several printed works coming out around this time, and in those contexts, there could be no question that they were meant seriously. We might think that the Elizabethans should have laughed at them, but he sees no reason to suppose that they did. ${ }^{8}$ And recently, Mytili Kaul has shown that they do not differ much from what Bacon thought worth setting down in his essay "Of Simulation and Dissimulation." It is not the maxims themselves that make Polonius a fool, she argues, but "the obvious incongruity or disproportion" between his utterance and what he is applying it to. ${ }^{9}$ I find these latter views convincing. Whether or not we find the maxims impressive, they are an accurate enough portrayal of humanist teachings to make Polonius, fool or no fool, a representative of the standard schooling.

When Polonius begins to query his daughter, we get an idea of how this standard schooling worked in practice. One examines a situation and then fits it to whatever maxims seem best to correspond to it. Polonius knows from common hearsay that princes of the blood do not always tell truth when they speak of love, but he knows more than that. He has a neat, metaphorical grasp on the whole general principle of such behavior:

I do know,

When the blood burns, how prodigal the soul

Lends the tongue vows. These blazes, daughter, 
Giving more light than heat, extinct in both

Even in their promise, as it is a-making,

You must not take for fire. $(1 \cdot 3 \cdot 115-120)$

And because he grasps the principle, he can configure the present situation within another metaphor:

Do not believe his vows, for they are brokers,

Not of that dye which their investments show,

But mere implorators of unholy suits,

Breathing like sanctified and pious bonds,

The better to beguile. (1.3.127-131)

The mind thus works from the specific situation to the maxim that covers it, and then back to the specific situation, which it now confidently grasps in metaphor, thus rendering it fully understood.

As a process, this does not differ markedly from what we call scientific thinking, for a situation is made an instance of a general law, and the law, once invoked, explains the situation. The thing that is different, and enormously so, is the quality of the covering maxims. The difference is huge between an evaluative metaphor and a scientific law. Both are instruments of understanding, but the metaphor - or the flat maxim which a metaphor may express and vivify - has a different relation to a competing metaphor than does a scientific law to a competing scientific law. Two competing scientific laws cannot both be true; if one is verified, it is set down alone in the book of wisdom, and the other one is discarded and forgotten. If one can find a law which does apply to a situation, one can be sure that no other law will displace it. With metaphors and maxims, on the other hand, this is not the case. The same page of the same book of wisdom can say both that "haste is waste" and that "a stitch in time saves nine," yet each of these propositions seems absolute when invoked, and each seems to have the force of law. The great problem with "phrase thinking" is that when one finds a phrase which seems plausible to think, it may not be the right one. It may turn out, in fact, that a totally contradictory phrase was the right one, and nothing in one's phrase training, per se, could have chosen between the two. This was a matter which humanist education did not handle well. It supplied maxims, but it could not regulate their use.

Polonius himself gives a splendid instance of what this problem entailed. By Act II, Hamlet is behaving strangely, providing new phenomena for evaluative maxims to cover. So long as Hamlet was behaving like an ordinary seducing prince, Polonius is confident that love is not involved. 
But new behavior demands new maxims, and when he hears that Hamlet appeared before Ophelia

$$
\text { with his doublet all unbrac'd, }
$$

No hat upon his head, his stockins fouled,

Ungart'red, and down-gyved to his ankle,

Pale as his shirt, his knees knocking each other,

And with a look so piteous in purport

As if he had been loosed out of hell

To speak of horrors (2.1.75-81)

his conclusion is instant. "Mad for thy love?" - it seems the only hypothesis, in view of the fact that Ophelia had denied Hamlet access to her.

I am sorry that with better heed and judgment

I had not coted him. I fear'd he did but trifle

And meant to wrack thee, but beshrow my jealousy!

By heaven, it is as proper to our age

To cast beyond ourselves in our opinions,

As it is common for the younger sort

To lack discretion. (2.1.108-114)

First, we should note that he has changed his maxim:

This is the very ecstasy of love,

Whose violent property fordoes itself,

And leads the will to desperate undertakings

As oft as any passions under heaven

That does afflict our natures. (2.1.99-103)

Second, he is aware that he has changed his maxim, and he finds that troubling. But third - and this makes everything all right again - he has another maxim to explain his wrong choice of maxim. It is a known property, after all, of men his age to "cast beyond" themselves in their opinion - just as, and in the same way, it is a property of youth to lack discretion. Tidiness has now returned to his thoughts, and all the phenomena, including his own mistake, are now covered; things are understood. It is a neat example of humanist thinking - not at its very best, to be sure, but representative of how it works and what its pitfalls are. Polonius is now certain, and though we know more than he, and may therefore regard his certainty with ironic amusement, we might note that given the state of his 
knowledge, nothing in his method is really wrong. He is doing what he was trained to do, and, alas for him, circumstances will not bear him out.

At this point, certainty in hand, Polonius is ready to present his findings to the king and queen. The focus now shifts from methods of discovering the truth to methods of presenting it. This, as we remember from the play, requires an oration. If the maxims of Act I have met a mixed reception, among the critics, the oration by Polonius in Act II has not. By general agreement it is folly; disagreement is only over what the folly points to. Here, it is useful to follow what the older commentators made of it. Warburton saw the oration scene as a neat exposé of elaborate presentations: "a fine satire," he calls it, "on the impertinent oratory then in vogue, which placed reason in formality of method, and wit in the gingle and play of words." 10 Samuel Johnson, however, did not think that Warburton went far enough. The "part of his character" which satirized the social practice of oratory "is accidental," Johnson says, "the rest is natural."

Such a man is positive and confident, because he knows that his mind
was once strong, and knows not that it has become weak. Such a man
excels in general principles, but fails in the particular application. He is
knowing in retrospect, and ignorant in foresight. While he depends upon
his memory, and can draw from his repositories of knowledge, he utters
weighty sentences, and gives useful counsel; but as the mind in its
enfeebled state cannot be kept long busy and intent, the old man is
subject to sudden dereliction of his faculties, he loses the order of his
ideas, and entangles himself in his own thoughts, till he recovers the
leading principle, and falls again into his former train. The idea of dotage
encroaching upon wisdom, will solve all the phaenomena of the char-
acter of Polonius.11

Johnson saw a deep and general human sadness in Polonius and gave full credit to Shakespeare for seeing it, too. He transfers our attention from the social practice of presentation oratory to a personal struggle which Polonius is having, and which, though personal, is something all humanity must share. Caldecott, in 1810 , sees the personal struggle, but is not convinced of its general sadness. He is not sure there ever was an intellect or competency in Polonius to be extinguished: "the very quality relied upon by Dr. Johnson," he says, "appears to us that which most strongly indicates imbecility of mind, viz. having the memory stored with sage rules and maxims, fit for every turn and occasion, without the faculty of making effective use of them upon any." 12 We may note that the problem of maxims, which I think was originally meant as a reflection on humanist training 
generally, has become for Caldecott simply an index of personal debility. A half century later, the Rev. C. E. Moberly added the modest reminder that "the use of language like that of Polonius" did not "argue the complete folly that it would at the present time." 13 "The present time" had forgotten what humanism was all about and had foreshortened Polonius into a particular imbecile, rather than a representative one, discarding whatever general or social moral his folly might have meant.

Moberly is right; but in just what way does Polonius's oratory reflect on the training that promoted it? Let it first be said that Polonius has reason to be proud of himself for solving the Hamlet mystery. Of course his solution is inadequate, but we know a lot of things he does not know, and we cannot assume that if he had our knowledge he would have maintained the opinion he now has. The problem, here, is not his lack of knowledge but the standard practice of separating the discovery of knowledge from its exposition. The strategies of these two mental processes were very different. Once one "knew" something, one's job was to cast all doubt aside and to give it the airtight exposition of absolute truth. Exposition was as much for presenting certainty itself as for presenting matter for which certainty was claimed. One sorted out one's matter into its elements, ironed out all possible contradictions, and reassembled the whole into a synthetic concord. If maxim-based security is inadequate, argued and arranged maxim-based security is inadequacy compounded.

The elements of the Polonian solution are simple: remove the object of a man's affection, and the vital spirits within, having no channels of release, will overflow and create insanity. Ophelia, in this case, is the object; her removal from Hamlet caused his madness. Two more things about the situation need explaining: first, that Ophelia really was the object of Hamlet's affections - and for this Polonius produces Hamlet's letter to her and reads it with a flourish; second, that removing her was an appropriate thing to do, given that it led to such a disastrous outcome - and for this Polonius defends himself as one well versed in the importance of keeping distinction between princes and subjects. Upon this armature, Polonius composes a small oration complete with proem, narratio, refutatio, and climax.

The oration is not delivered in a polished or even competent fashion, and that, rather than the oration itself, is the source of Polonius's silliness. His attention wanders from the point on several occasions, and there is major ironic discrepancy between his grand gestures of certainty and what we know about the situation he claims so well to understand. Wandering attention makes Polonius a fool, but the discrepancy can be laid upon the 
limitations of what he has been trained to do. Thinking of this kind is the going thing, after all, and if it does not work, that problem seems to be a general theme of this play. Hamlet is the tragedy of the going thing that does not work.

I should mention two other aspects of Polonius which place him as a representative of humanist training: his claim to be a shrewd judge of literature and style, and his interest in being a clever intriguer. It might seem odd to put those two together, since the one is associated with schoolmasters and the other with ambitious, would-be Machiavels, but in the careers at least of Gabriel Harvey and Francis Bacon the two interests were found together. The parallels are not perfect, for Bacon was not the kind of man to stand behind arrases and Harvey never got the chance. Both men were stylists; however, both believed that the well-trained speaker could master the affairs of men, and both were proved wrong by events. ${ }^{14}$ Bacon, at least, believed in the cunning art of "indirections find[ing] directions out" (2.1.63), a version of which, translated out of politics and into natural history, became Bacon's contribution to the history of science. ${ }^{15}$ It should be noted, as an aside, that when the play comes to the matter of literature and style, it takes an interesting twist: Polonius is now the modern and Hamlet the old-fashioned humanist. Hamlet responds to the Player King's words with tears in his eyes, like humanism's perfect pupil, the words having touched him as humanist doctrine always promised words would do. Polonius responds to the words as grammatical entities and bits of a lexicon; if Hamlet is the old-fashioned pupil (for the moment), Polonius is the typical teacherly sort of humanism's latter days: expertise in language, for him, has become its own reward.

Polonius, then, is Shakespeare's last humanist. He is as silly as Holofernes, the schoolmaster of Love's Labors Lost, but vastly more important. He is snapped up in events too big for him, like Cinna the Poet in Julius Caesar. ${ }^{16}$ And, in a way more grimly funny than tragic, he is as futile as Brutus, that hero of so many humanist diatribes, whose attempt to make the world an image of his speech so signally fails. But if Polonius is a representative of humanist training, so what? How would that make a difference in reading the play?

First, and most obviously, we would not read Polonius as an absolute fool, though that, by itself, cannot matter much. But if we see in his folly the built-in limitations of the way in which Renaissance intellectuals were trained, we have some interesting things to think about. For if there is one salient characteristic of humanist training, it is its confidence. Humanists were confident that the authorities from which they had their maxims were 
both relevant and wise. It bred confidence to have a situation and a maxim come clicking together in the mind, and if that maxim had metaphorical vividness, the confidence was compounded, because the transforming power of metaphor tends to totalize: once a metaphor is set going, all nearby phenomena are drawn into its force-field. Then there were the modes of exposition, which transmitted confidence at least as much as they transmitted actual information. All this worked very well, so long as situations were not strange. But Hamlet, of course, sets up a strange situation, and under the stress of this strangeness, the limitations of this confidence become glaringly clear.

What happens in Hamlet is that the confident minds are mediocre and that their mediocrity is a function of their confidence. This insight, however, is given several additional twists. First, the play presents no positive systems or procedures that we can think are better than humanism; the better minds are marked only by their negative capabilities. "O day and night," cries Horatio, "but this is wondrous strange!" "And therefore," replies Hamlet, "as a stranger give it welcome" (1.5.164-5). Second, though confidence and mediocrity are severely punished in this play, cunning and negative insight do not fare that much better. The price for refusing to be confidently wise is to wind up accepting a world of no distinctions whatever, where the guts of Julius Caesar - or Polonius - are all the same to the worm that eats them. And third, at the end of the play Hamlet enjoins Horatio to stay alive in this meaningless world so as to tell Hamlet's story properly. The world means nothing at all, perhaps, but Horatio is to take on a humanist's role anyway, the task of rightly charactering the memories of those who come after. Hamlet seems here to think that it makes a difference to have this done and that Horatio will do it properly. Humanism, so rudely ushered out the front door of this play, has crept in at the side window. To see Polonius simply as a fool, then, is to relax one's focus on this tangled web of humanist enterprises and the assumptions and practices they are based on. Why relax one's focus on something so interesting as this? To my mind, at least, there is more payoff from seeing Polonius as a representative humanist than from making him mere geriatric comic relief.

\section{University of Washington}

\section{Notes}

1 All citations from The Riverside Shakespeare, ed G. Blakemore Evans, et al. (Boston: Houghton Mifflin, 1974).

2 The Question of Hamlet (New York: Oxford University Press, 1959), p. 25. 
3 Mentioned by Levin L. Schcking, Character Problems in Shakespeare's Plays (New York: Henry Holt, 1922), p. 105.

4 Lynda Boose, "The Fashionable Poloniuses," Hamlet Studies 1 (1979), 76.

5 Dowden is quoted by Josephine Waters Benneth, "Characterization in Polonius's Advice to Laertes," Shakespeare Quarterly 4 (1953): 3, n.1; Derek Traversi, An Approach to Shakespeare, 2nd ed. (New York: Doubleday Anchor, 1956), p. 86; Boose, p. 73.

6 Character Problems, pp. 103-09, passim.

7 Bennett, "Characterization," as cited note 5.

8 Hunter, "Isocrates' Precepts and Polonius' Character," Shakespeare Quarterly 8 (1957): 501-06.

9 Kaul, "Hamlet and Polonius," Hamlet Studies 2 (1980), 15-16.

10 Quoted by Arthur Sherbo, ed., Johnson on Shakespeare, The Yale Edition of Samuel Johnson, vol VIII (New Haven and London: Yale University Press, 1968), p. 973.

11 Ed. Sherbo, p. 974.

12 Quoted by Horace Howard Furness, ed., Hamlet, 2 vols (1877), A New Variorum Edition of Shakespeare, vols 3 and 4 (repr. New York: American Scholar Publications, 1965), I, 136.

13 Quoted Furness, I, 136.

14 Harvey, sometime Cambridge professor of Rhetoric and would be "politique," never rose to the eminence for which he thought himself qualified. For Bacon see the brilliant article by F. J. Levy, "Francis Bacon and the Style of Politics," English Literary Renaissance, 16 (1986): 101-122, which not only tells the story of the moment when Bacon, in Parliament, actually tried to play the role of decisive humanist orator (only to fail and nearly derail his career), but argues that the style of his 1597 Essays may be seen as a deliberate attempt, in the realm of prose style, to reject the ideals of humanism as naive.

15 Bacon's idea of inductive method, in The New Organon, was to approach the explanation of phenomena not directly, with received ideas in mind, but indirectly, by observation only, waiting for the ideas that genuinely control them to suggest themselves.

16 Cinna the poet's little episode does not amount to much in the play, but it is an ironic reflection on the high-toned humanist notion that poets speak to nations, shape their destinies, and define the virtues of their people. 